\title{
Nawrót choroby nowotworowej - emocjonalne konsekwencje i możliwości psychologicznej pomocy
}

\section{Cancer relapse - emotional consequences and possibilities of psychological help}

\author{
Marta Zagozda ${ }^{1}$, Maria Litwiniuk ${ }^{1,2}$, Michał Ziarko³ \\ ${ }^{1}$ Wielkopolskie Centrum Onkologii \\ ${ }^{2}$ Katedra i Zakład Profilaktyki i Patologii Nowotworów Uniwersytetu Medycznego $w$ Poznaniu \\ ${ }^{3}$ Instytut Psychologii Uniwersytetu im. A. Mickiewicza w Poznaniu
}

\section{Strzeszczenie}

Nawrót choroby nowotworowej negatywnie obciąża pacjenta nie tylko somatycznie, ale również psychicznie i społecznie. Staje się źródłem silnego stresu i uruchamia różnorodne, nieprzyjemne, intensywne reakcje emocjonalne jak: rozpacz, niepokój, bezradność, poczucie winy, żal, smutek. Czasami reakcje te potrafią być zdecydowanie silniejsze niż wtedy, gdy diagnoza stawiana była po raz pierwszy, nawet jeśli pacjent miał świadomość ryzyka nawrotu. Niektóre z doznań pacjenta stają się na tyle silne i niekorzystne, że wymagają specjalistycznej pomocy. Taką jest np. sytuacja, gdy pacjent rezygnuje z leczenia, pomimo realnych szans na odniesienie z niego korzyści lub myśli o przerwaniu cierpienia przez popełnienie samobójstwa.

Praca uwzględniając perspektywę obserwacji klinicznych oraz dotychczasowe doniesienia z literatury przedmiotu w ramach psychologii zdrowia oraz psychoonkologii ma na celu ukazanie w jaki sposób pacjenci reagują na informację, że choroba powróciła oraz które z tych zachowań i kiedy wymagają reakcji ze strony lekarza czy innych osób uczestniczących w procesie leczenia i opiece nad pacjentem. W pracy omówione także zostaną formy pomocy psychologicznej pacjentom w radzeniu sobie z sytuacją nawrotu.

\footnotetext{
Abstract

Adres do korespondencji

mgr Marta Zagozda

Młodszy Asystent - Psycholog

Wielkopolskie Centrum Onkologii,ul. Garbary 15, 61-866 Poznań, Polska

Telefon: +48618850882

e-mail: marta.zagozda@wco.pl
}

Cancer relapse affects the patient negatively not only in the somatically, but also in psychologically and socially. It is again the source of strong distress and causes different, unpleasant, intensive emotional reactions such as: despair, anxiety, helplessness, sense of guilt, sorrow and sadness. The reactions can sometimes be definitely stronger than when the diagnosis was made for the first time, even if the patient was aware of the risk of relapse. Some of the reactions can be so strong and adverse that they require professional help, e.g. when the patient stops treatment although the therapy could be helpful or considers committing suicide to 
stop the suffering.

The paper, taking into account clinical observation and existing literature on psychology of health and psychooncology, is aimed to present the emotions of patients to the information that the disease has recurred and discuss which of them and when they demand reactions of medical staff and other people taking care of the patients. The paper also describes different forms of psychological support to help patients cope with cancer relapse.

Słowa kluczowe: rak; nawrót choroby; bezradność; lęk, jakość życia

Keywords: cancer; disease return; helplessness; fear; quality of life

\section{Wstęp}

Nawrót choroby to określenie sytuacji ponownego pojawienia się choroby nowotworowej. Proces ten rozpoczyna się od komórek nowotworowych, które przetrwały pierwsze leczenie i wraz z upływem czasu zwiększyły swą liczbę, doprowadzając do powstania zmian, które mogły zostać wykryte w badaniu przedmiotowym i badaniach obrazowych. Z uwagi na umiejscowienie zmian wyróżnia się następujące rodzaje nawrotu:

- nawrót lokalny, czyli pojawienie się nowotworu w tym samym miejscu, w którym zmiana była zlokalizowana pierwotnie bądź bardzo blisko tego miejsca,

- nawrót regionalny, gdy choroba rozwija się np. w węzłach chłonnych bliskich pierwotnej lokalizacji lub w pobliżu tego miejsca,

- nawrót odległy, gdy nowotwór rozprzestrzenił się do nowego miejsca, odległego od miejsca pierwotnego. Mamy wtedy do czynienia z chorobą rozsianą np. gdy pierwotnie leczony był rak piersi, a przerzut pojawił się w kościach bądź wątrobie [1].

Zdarza się także, choć jest to sytuacja rzadka, że choroba powraca jako nowy nowotwór (niezależny) niepowiązany z pierwotnym rozpoznaniem.

Pacjent powinien być zawsze informowany o możliwości nawrotu choroby. Czasem jednak do nawrotu dochodzi po wielu latach. Tak bywa w przypadku raka piersi wykazującego ekspresję receptorów estrogenowych - więcej nawrotów powstaje po 5 latach od rozpoznania choroby niż w okresie wcześniejszym [2]. Choroba pojawia się więc w okresie, gdy chory odzyskuje względne poczucie bezpieczeństwa.

Ponowne pojawienie się choroby, niezależnie od lokalizacji, nie oznacza, że zastosowana terapia onkologiczna była niewłaściwa bądź, że doszło do zaniedbania ze strony pacjenta [1]. Ważne jest precyzyjne określenie aktualnej sytuacji zdrowotnej: w przypadku nawrotu lokalnego często możliwe jest radykalne leczenie operacyjne, podczas gdy u chorego z odległymi przerzutami leczenie najczęściej ma charakter postępowania paliatywnego. Wyleczenie możliwe jest jednak również u chorego z chorobą rozsianą. Tak jest w przypadku nowotworów wrażliwych na chemioterapię (np. rak jądra) lub gdy możliwe jest operacyjne leczenie ograniczonej liczby przerzutów (np. rak jelita grubego) [3].

Większość osób, które zmagały się z chorobą nowotworową, ma świadomość ryzyka nawrotu. Mimo to informacja, że choroba powróciła, może wywołać wiele silnych reakcji emocjonalnych, podobnie jak przy pierwszym rozpoznaniu. Pojawić się może:

\section{- szok, niedowierzanie, zaprzeczanie}

Wyraża się w słowach: „To nie może być prawda”, „Tojakaś pomytka”, „To się nie dzieje naprawdę”, „Jak to możliwe, że ponownie mi się to przytrafia”. To początkowo korzystny, a nawet czasem najlepszy i najczęściej występujący mechanizm radzenia sobie z informacją o diagnozie, z której chory często nie tylko dowiaduje się, że choroba powróciła, ale także, że tym razem może okazać się nieuleczalna, a przewidywana terapia nastawiona będzie na wydłużenie życia i zadbanie o jego jakość, a nie na odzyskanie pełni zdrowia. Chory, broniąc się przed przyjęciem informacji, że odzyskane zdrowie, przywrócona aktywność i wypracowane nowe 
podejście do życia ponownie zostanie zakłócone, może próbować uporczywie udowadniać, że to nie nastąpi np. przez kolejne konsultacje, badania - wszystko to, co mogłoby zanegować informacje. Może również unikać dowodów potwierdzających, że życie jest zagrożone poprzez unikanie konkretnych osób, miejsc, informacji. Zaprzeczenie to swoisty bufor po doznaniu wstrząsu, który pozwala choremu na opanowanie się, zmobilizowanie sił i uruchomienie mniej radykalnych sposobów radzenia sobie. Siła mechanizmu negacji może zależeć od tego, w jaki sposób pacjent usłyszał diagnozę, ile czasu upłynęło od jej otrzymania, oraz jakie ma doświadczenie życiowe w radzeniu sobie z krytycznymi zdarzeniami - zwłaszcza jak wcześniej przebiegała choroba, jaki posiada obraz własnej choroby i percepcję własnej sytuacji, oraz jak choroba postrzegana jest w rodzinie, włącznie z doświadczeniem choroby nowotworowej wśród innych członków rodziny [4-9].

\section{- złość}

Ujawnia się w wypowiedziach: „Czemu to ponownie mnie spotyka?”; „Czy to co przeszedtem do tej pory nie powinno już wystarczyć?” Uczucia gniewu, złości, wściekłości, rozżalenia zajmują często miejsce po obserwowanym szoku i zaprzeczeniu. Chory przestaje negować diagnozę o nawrocie i zaawansowaniu, a zaczyna zastanawiać się: Dlaczego on? Dlaczego jego to spotkało? To moment trudny zwłaszcza dla rodziny i otoczenia chorego, które może stać się odbiorcami jego gniewu. Ważna, wówczas jest świadomość, że zachowanie to jest najczęściej zupełnie przypadkowe, a jego ekspresja powinna być raczej odczytywana jako próba zamanifestowania potrzeby uwagi, szacunku, miłości i akceptacji, a także chęci odzyskania choćby namiastki kontroli $[4,5]$.

\section{- smutek, przygnębienie, bezsilność, bezradność, beznadzieja}

Ekspresja tych emocji jest subtelna i najczęściej przebiega w milczeniu. Chory jakby pomiędzy wierszami, nierzadko przez łzy mówi: „to już koniec”, „nie ma dla mnie nadziei”, „pewnie niedługo umrę, „strace wszystko, co kocham”. Dzieje się tak, ponieważ, pacjent skonfrontowany z niekorzystnymi informacjami medycznymi i beznadziejnością swej sytuacji może mieć poczucie „wielkiej straty”, która przybiera różne wymiary: poczucie utraty samego życia, najbliższych, własnego wyglądu, ale też zawodowych osiągnięć, pieniędzy itp. W tym czasie milczenie potrzebne jest też ze strony opiekunów, którzy swą miłość i troskę mogą lepiej wyrazić gestem, niż słowem [4-9].

\section{- przerażenie, strach, lęk}

„Co teraz ze mną będzie, jak sobie poradzę, czy wytrwam?”. Lęk może przybierać różne oblicze odnosząc się bezpośrednio do pacjenta, do najbliższych - dalszej możliwości uczestniczenia w ważnych momentach w życiu rodzinnym, do terapii - jej konsekwencji i skuteczności, do kresu życia - śmierci, bólu, duszności. Często dostępne pacjentowi słowa wydają się niewystarczające i nieadekwatne do opisu świata wewnętrznego, sparaliżowanego strachem $[4,5,10]$.

Wśród innych równie często obecnych reakcji emocjonalnych i zachowań pojawia się poczucie winy, wyrażane w słowach: „coś zaniedbałem”, „coś zrobiłem nie tak”. Osamotnienie, izolacja, którą sygnalizują wypowiedzi: „nikt kto tego nie przeżyt, nie zrozumie”. Targowanie się - chory próbuje podjąć negocjacje z bogiem, z ludźmi, o dłuższe życie, o jeszcze jedną szansę, o możliwość doświadczenia jeszcze jakiegoś ważnego zdarzenia - rodzinnego, zawodowego. W zamian pada wiele obietnic, np. dobrego sprawowania, dobrych uczynków. Większość tych negocjacji prowadzonych jest na osobności lub chory wspomina o nich jakby mimochodem. Ważne, by je wyłapywać i nie lekceważyć, gdyż mogą być sygnałem zmagania się przez chorego z trudnymi emocjami, jak poczucie winy, czy niewyrażonymi potrzebami. Obecna jest także nadzieja, ale często o zmienionym obliczu, gdyż wysiłek pacjenta, jego bliskich i personelu medycznego okazał się niewystarczający do zatrzymania choroby. Trudno w takiej sytuacji mieć nadzieję na ponowną remisję czy nawet jakąkolwiek skuteczność leczenia. Podstawą podtrzymania nadziei staje się skoncentrowanie na najbliższym okresie - nadzieja na brak dolegliwości, na przyśpieszenie badania, na możliwość spotkania się 
$\mathrm{z}$ bliskimi lub uczestniczenia $\mathrm{w}$ ważnym wydarzeniu rodzinnym $\mathrm{w}$ dobrym samopoczuciu [10,11].

Odpowiedź emocjonalna chorego na informację o diagnozie nawrotu i zaawansowaniu choroby ma silnie zindywidualizowany charakter i może przebiegać niezwykle dynamicznie, powodując, że poszczególne doznania mogą pojawiać się równocześnie, powracać czy też całkowicie się nie ujawniać.

Wszystkie wymienione emocje, obawy, troski, ale też nadzieje są bardzo ważne. Potrzebne jest przyzwolenie na ich odczuwanie, bez poddawania ocenie. Może się zdarzyć, że reakcje będą nawet silniejsze niż za pierwszym razem. Jest to naturalne i pozwala przygotować się na ponowne podjęcie przez pacjenta zmagań z chorobą. Poznanie świata przeżyć chorego pomaga też jego opiekunom i osobom leczącym. Mogą oni dzięki temu lepiej zrozumieć czego chory najbardziej potrzebuje, jak zapewnić mu najlepszą opiekę [12,13].

Zatem nawrót choroby jest nie tylko nowym, trudnym wyzwaniem, ale jest też powtórzeniem wielu doświadczeń, z którymi może być teraz łatwiej sobie poradzić. Wcześniejsze doświadczenie choroby i leczenia wyposażyło chorego w:

- świadomość, że chorobę można przezwyciężyć,

- wiedzę o dostępnych metodach leczenia,

- umiejętność przygotowania się do leczenia, rozmowy z personelem medycznym; znajomość pomocnych sposobów radzenia sobie z odczuwanymi dolegliwościami,

- praktykę kto jest osobą potrafiącą okazać adekwatne wsparcie, na kogo można liczyć, z kim można porozmawiać o swojej sytuacji i do kogo zwrócić się o pomoc,

- większą świadomość odczuwanych emocji,

- zdolność do rozpoznawania i wyrażania potrzeb oraz oczekiwań [1,12].

To wszystko może stać się bardzo pomocne na nowej, a zarazem w jakimś stopniu już znanej drodze do ponownej walki o zdrowie.

Czasami jednak niełatwo jest przywrócić równowagę psychiczną, która została zachwiana ponowną diagnozą. Cała sytuacja wydaje się niemożliwa do wytrzymania. Wymienione wcześniej odczucia, zwłaszcza przygnębienie czy niepokój, zaczynają się nasilać, wypełniając ponad połowę czasu nieprzeznaczonego na sen. To powoduje, że codzienne funkcjonowanie ulega zakłóceniu, a przerwanie tego stanu własnymi siłami wydaje się w tym momencie niemożliwe. U chorego mogą pojawić się zaburzenia dezadaptacyjne, które dzieli się na zespoły lękowe, depresyjne i pod postacią mieszaną z dużą komponentą gniewu i buntu. Są to, obok zespołów neuropsychiatrycznych, najczęściej rozpoznawane zaburzenia psychiczne wśród chorych onkologicznie. Zespół lękowy obejmuje objawy psychiczne, wegetatywno-somatyczne i behawioralne. U chorego obserwuje się:

- napięcie emocjonalne,

- trudności z odwróceniem uwagi od uporczywych myśli wywołujących silny lęk czy ataki paniki, np. myśli o braku nadziei na powodzenie leczenia i chęć wycofania się z terapii, myśli o utracie sprawności, pełnionych przez siebie rolach czy myśli o śmierci,

- nasilające się trudności poznawcze m.in. w obszarze pamięci, uwagi i koncentracji oraz pojawiające się zniekształcenia poznawcze jak np. nieadekwatna poznawcza reprezentacja choroby oraz zawężenie pola postrzegania swojej sytuacji,

- wesołkowatość, sztuczny śmiech (cechy niezauważane wcześniej),

- nerwowość, drażliwość,

- wzmożone napięcie mięśni - drżący głos, drżenie rąk, drżenie ciała,

- pobudzenie albo zahamowanie ruchowe,

- bladość, „skamienienie”,

- skulona postawa, unikanie wzroku,

- suchość w jamie ustnej,

- rozszerzenie źrenic,

- tachykardia; wzrost RR; hyperwentylacja; ból za mostkiem,

- zaburzenia zasypiania; koszmary nocne,

- wzmożona potliwość,

- zmiany biochemiczne [14-17]. 
Podstawę rozpoznania zespołu lękowego stanowi rozmowa z pacjentem i obserwacja jego zachowania. Pomocne mogą okazać się także narzędzia takie jak: Szpitalna Skala Lęku i Depresji (ang. Hospital Anxiety and Depression Scale, HADS), czy Inwentarz Stanu i Cech Lęku (ang. Spielberger's State-Trait Anxiety Inventory, STAI) [14].

Symptomy zaliczane do zespołu depresyjnego to:

- obniżony nastrój,

- ruminacja pesymistycznych myśli,

- płaczliwość - płacz wielokrotnie w ciągu dnia lub przez dłuższy czas,

- bezradność, bezsilność, beznadzieja,

- nieadekwatne poczucie winy,

- brak zdolności cieszenia się - anhedonia,

- brak sensu życia,

- myśli rezygnacyjne i zamiary samobójcze - sytuacja wymaga natychmiastowej interwencji w postaci konsultacji psychiatrycznej, jeśli chory zaplanował w jaki sposób i kiedy odbierze sobie życie,

- pogorszenie koncentracji i uwagi,

- brak zainteresowania aktywnościami, które dotychczas sprawiały przyjemność jak np. czas spędzany z rodziną, przyjaciółmi, zajmowanie się swoimi pasjami,

- utrata motywacji i mobilizacji np. odmowa podjęcia czy kontynuacji terapii, mimo realnych szans na odniesienie z niej korzyści,

- zmniejszenie aktywności, izolowanie się od otoczenia,

- wzrost męczliwości,

- utrata apetytu,

- zaburzenia snu - bezsenność, wielokrotne wybudzanie się, przerywany i płytki sen,

- ogólne spowolnienie psychoruchowe, bez zmian w stanie somatycznym.

Jeżeli wywiad oraz obserwacja pacjenta i/lub informacje uzyskane od bliskich wskazują na obecność powyższych zaburzeń dezadaptacyjnych, obowiązkiem lekarza, zajmującego się nie tylko dolegliwościami fizycznymi, ale także dyskomfortem psychicznym, społecznym i duchowym, jest uruchomienie odpowiedniej pomocy. Może nią być wskazanie i mobilizowanie do wizyty u lekarza psychiatry, celem postawienia dokładnego rozpoznania klinicznego i wdrożenia odpowiedniego leczenia farmakologicznego lub/i konsultacja z psychologiem [18, 19].

Istotne jest, by pacjent, który doświadcza tego rodzaju cierpień psychicznych, mógł otrzymać odpowiednią i przysługującą mu pomoc. Psychologiczne świadczenia zdrowotne powinny być dostępne dla każdego pacjenta zmagającego się z psychicznymi następstwami nawrotu choroby, zarówno w publicznych jak i niepublicznych podmiotach leczniczych. Psycholog postępując zgodnie ze standardami psychologicznych świadczeń zdrowotnych opracowanych przez Polskie Towarzystwo Psychologiczne w 1999 r., zwraca uwagę na znaczenie czynników psychologicznych dla stanu chorego i decyduje o podejmowanych działaniach, dostosowując odpowiednią pomoc, na którą chory musi wyrazić zgodę [20]. Wśród rodzajów świadczeń psychologicznych w podmiotach leczniczych możemy wymienić:

- poradę psychologiczną - służy rozwiązaniu problemu zgłaszanego przez pacjenta, jego rodzinę lub opiekuna,

- konsultację psychologiczną - odnosi się do wykonania badania stanu psychicznego pacjenta metodami psychologii klinicznej; obejmuje psychologiczną diagnozę problemową i sformułowanie wskazań odnośnie dalszego postępowania z pacjentem,

- terapię psychologiczną - obejmuje złożony proces różnorodnych oddziaływań psychologicznych, nastawionych na pomoc choremu i jego rodzinie lub opiekunowi w: zrozumieniu i akceptacji choroby w jej aktualnej, zmieniającej się postaci; wytwarzaniu właściwej motywacji do różnych form aktywności; dokonywaniu niezbędnych na skutek zaistniałej choroby zmian w funkcjonowaniu społecznym; akceptacji życia z dysfunkcją lub kalectwem; utrzymaniu i rozwijaniu kontaktów społecznych,

- interwencję w kryzysie - udzielanie pomocy w kryzysie psychologicznym wywołanym chorobą i jej 
okolicznościami,

- rehabilitację psychologiczną - złożony ciąg oddziaływań psychologicznych i zastosowanie programów ćwiczeń, celem rozwijania lub przywracania sprawności i aktywności życiowej chorych z rozmaitymi dysfunkcjami ośrodkowego układu nerwowego,

- psychoterapię - przepracowanie podstawowych problemów i trudności pacjenta w ustalonym cyklu spotkań [20].

W kontekście wymienionych wcześniej zaburzeń psychicznych jak zespoły depresyjne i lękowe użyteczne są zwłaszcza takie formy pomocy jak: konsultacja psychologiczna, porada psychologiczna, terapia psychologiczna lub interwencja w kryzysie. Natomiast cel terapeutyczny tj. obniżenie poziomu lęku czy poprawa nastroju, może zostać osiągnięty poprzez wdrożenie oddziaływań terapeutycznych takich jak:

- zapewnienie wsparcia głównie emocjonalnego i informacyjnego,

- $\quad$ pomoc w ekspresji emocji i poprawa komunikacji,

- pomoc w umożliwieniu przystosowania się do doświadczanej zmiany życiowej - odzyskanie kontroli i możliwości radzenia sobie z konsekwencjami choroby,

- $\quad$ pomoc w poprawie/odzyskaniu jakości życia w obliczu zmian wywołanych chorobą [21, 22, 23].

Zatem, istotnym zadaniem psychologa, będzie okazanie wsparcia emocjonalnego. Specjalista swoim działaniem pomoże choremu wyrazić nieprzyjemne, tłumione uczucia. Umożliwi to poprawę nastroju i odczucie pożądanej ulgi. Najczęściej równolegle ma miejsce wsparcie informacyjne. Osoba pomagająca dostarcza ogólnych wiadomości i pomaga w zrozumieniu posiadanych przez chorego informacji odnośnie: problemu nawrotu choroby, skuteczności środków zaradczych, konsekwencji, jakie niesie za sobą wybrany sposób leczenia lub brak poddania się proponowanej terapii. Wsparcie jest więc pomocą w przywróceniu poczucia kontroli i stabilności oraz zwiększeniem możliwości opanowania stresu związanego z chorobą [23, 24].

Psycholog, pracując nad obszarem emocjonalnym chorego, pozwala mu lepiej zrozumieć, wyrazić i poradzić sobie z wieloma, trudnymi emocjami jak: strach, lęk, niepewność, przygnębienie itp. Daje także do zrozumienia, że to, co pojawia się w sferze emocji, co dana osoba czuje w tym okresie, jest ważne i nie ma podstaw by to ukrywać, wstydzić się czy obwiniać się za to. Zatem specjalista pracuje z chorym nad zmianą sposobu myślenia o problemie. Stara się także poprawić komunikację chorego z bliskimi jak i personelem medycznym. Często porozumiewanie się w obliczu choroby może zostać zaburzone i zamiast w tym trudnym, niezwykle wymagającym czasie zbliżać się do najbliższych czy wzmacniać współpracę w zakresie zdrowia, buduje dystans oraz wzajemne niezrozumienie, co może nasilać dolegliwości psychiczne pacjenta. Praca w tym obszarze może pozwolić m.in. na obniżenie napięcia, rezygnacji czy niechęci [13, 24].

Specjalista może pomóc choremu na raka w przystosowaniu się i zaakceptowaniu wielu zmian fizycznych, psychicznych, społecznych czy duchowych z którymi zderza się w obliczu nawrotu choroby. Towarzyszy i pomaga w sprawach ostatecznych, związanych ze śmiercią i odchodzeniem, o których nie łatwo myśleć, a tym trudniej rozmawiać $[17,24]$.

Psycholog może także zaproponować i zachęcić chorego do skorzystania z grup wsparcia czy oferty stowarzyszeń pacjenckich. Jest to możliwość otrzymania pomocy od osób o podobnych przeżyciach i doświadczeniach. Miejsca te mogą efektywnie pomóc przechodzić przez to krytyczne wydarzenie życiowe $[13]$.

\section{Podsumowanie}

Doświadczenie nawrotu choroby nowotworowej nierzadko dotkliwiej niż pierwsza diagnoza psychicznie obciąża chorego. Pomoc psychologiczna może pomagać w przywróceniu równowagi wewnętrznej, głównie poprzez zmniejszenie silnego napięcia emocjonalnego oraz polepszenie poczucia kontroli i stabilności. Może to wpłynąć na lepsze, silniejsze nastawienie do ponownego zmagania się z chorobą oraz może pomóc w podtrzymaniu zachwianej nadziei. Uruchomienie tej formy specjalistycznej pomocy w ramach interdyscyplinarnej opieki nad pacjentem z wznową choroby nowotworowej może przyczynić się do poprawy nastroju i jakości życia chorego, lepszego przebiegu procesu terapeutycznego oraz efektywniejszej współpracy 
z personelem medycznym [24,15].

\section{Konflikt interesu / Conflict of interest}

Nie występuje / None

\section{Etyka / Ethics}

Treści przedstawione w artykule są zgodne z zasadami Deklaracji Helsińskiej, dyrektywami EU oraz ujednoliconymi wymaganiami dla czasopism biomedycznych.

\section{Piśmiennictwo / References}

[1] Kowalska K, Podymniak E. Gdy nowotwór powraca. Poradnik dla osób z nawrotem choroby i ich bliskich. Warszawa: PRIMOPRO; 2016.

[2] Dowsett M, Cuzick J, Ingle J, et al. Meta-Analysis of breast cancer outcomes in adjuvant trials of aromatase inhibitors vs tamoxifen. J Clin Oncol 2010; 28: 509-518.

[3] Sadot E, Groot Koerkamp B, Leal JN, et al. Resection margin and survival in 2368 patients undergoing hepatic resection for metastatic colorectal cancer: Surgical technique or biologic surrogate? Ann Surg 2015; 262: 476-485.

[4] Kübler-Ross E. Rozmowy o śmierci i umieraniu. Poznań: Wydawnictwo Media Rodzina; 2007: 19-163.

[5] Mączka G. Człowiek umierający - psychologiczne aspekty opieki paliatywnej. W: Bętkowska-Korpała B, Gierowski JK. Psychologia lekarska w leczeniu chorych somatycznie. Kraków: Wydawnictwo Uniwersytetu Jagiellońskiego; 2007: 241-252.

[6] Widera A. Psychologiczne aspekty pacjenta z chorobą nowotworową. W: Bętkowska-Korpała B, Gierowski JK. Psychologia lekarska w leczeniu chorych somatycznie. Kraków: Wydawnictwo Uniwersytetu Jagiellońskiego; 2007: 67-82.

[7] Barraclough J. Rak i emocje. Warszawa: Wyd. Medyczne SANMEDICA; 1997: 50-91.

[8] Chojnacja-Szawłowska G. Psychologiczne aspekty przewlekłych chorób somatycznych. Warszawa: Vizja Press\&IT; 2012: 41-84.

[9] Pilecka B. Kryzys psychologiczny. Wybrane zagadnienia. Kraków: Wydawnictwo Uniwersytetu Jagiellońskiego; 2004: 73-106.

[10] Gałuszka A. Lęk, nadzieja i poczucie sensu życia u osób chorych przewlekle. W: Block B, Otrębski W. Człowiek nieuleczalnie chory. Lublin: WNS KUL; 1997: 267-275.

[11] .Gołąb D. Trudne sytuacje w opiece paliatywnej - możliwości pomocy psychologicznej. Psychoonkologia 2013; 4: 151-155.

[12] Krajnik M, Rogiewicz M, de Walden-Gałuszko K. Etapy chorowania orazleczenia przeciwnowotworowego i hematologicznego. W: Rogiewicz M. Praktyczny podręcznik psychoonkologii dorosłych. Kraków: Medycyna Praktyczna; 2015: 81-161, 179-222.

[13] Krajnik M. Opowieści o raku. Gdańsk: Wydawnictwo Via Medica; 2009: 26-30, 68-72, 86-89, 112-113, 162-165.

[14] De Walden-Gałuszko K, Ciałkowska-Rysz A. Medycyna Paliatywna. Warszawa: Wydawnictwo Lekarskie PZWL; 2015: 31-43, 181-193.

[15] De Walden-Głuszko K. Psychoonkologia w praktyce klinicznej. Warszawa: Wydawnictwo Lekarskie PZWL; 2011: 103-124, 127-130.

[16] De Walden-Gałuszko K. U kresu. Opieka psychopaliatywna, czyli jak pomóc choremu, rodzinie i personelowi medycznemu środkami psychologicznymi. Gdańsk: Wydawnictwo medyczne MAKmed; 1996: 20-41, 100-101.

[17] Rucińska M, Rogiewicz M, Chrystowska-Jabłońska B, de Walden- Gałuszko K. Stadium zaawansowane choroby nowotoworwej. W: Rogiewicz M. Praktyczny podręcznik psychoonkologii dorosłych. Kraków: Medycyna Praktyczna; 2015: 297-305. 
[18] Łuczak J. Cierpienie. Charakterystyka, rozpoznanie, wspomaganie cierpiących, powinności leczących, skuteczność pomocy cierpiącym chorym. W: Block B, Otrębski W. Człowiek nieuleczalnie chory. Lublin: WNS KUL; 1997: 68-95.

[19] 19. Heubner P. Aspekty związane z farmakoterapią zaburzeń psychicznych w onkologii.W: Dorfmuller M, Dietzfelbinger H. Psychoonkologia. Wrocław: Elsevier Urban \& Partner; 2009: 199-203.

[20] 20. Polskie Towarzystwo Psychologiczne. Standardy Psychologicznych Świadczeń Zdrowotnych. Warszawa 1999.

[21] Sęk H. Psychologia zdrowia. Warszawa: PWN; 2007: 196-209, 297-305.

[22] Poliget-Schoris D. Wskazania do interwencji psychoonkologicznych. W: Dorfmuller M, Dietzfelbinger H. Psychoonkologia. Wrocław: Elsevier Urban \& Partner; 2009: 47-50.

[23] Forshaw M. Advanced Psychology Health Psychology. Oxford: Oxford University Press; 2003: 48-55.

[24] Bret A, Boyer BA, Paharia MI. Comprehensive Handbook of Clinical Health Psychology. Hoboken: John Wiley \& Sons; 2008: 153-178. 